\title{
Functional and structural brain changes in patients with phantom limb pain
}

\author{
Shigeyuki Kan \\ Department of Anesthesiology and Intensive Care Medicine, \\ Osaka University Graduate School of Medicine
}

\begin{abstract}
Phantom limb is a sensation of a missing hand that patients feel after amputation, and phantom limb pain or phantom pain is a pain in a phantom limb. Phantom limb pain occurs in $45 \%-85 \%$ of amputees, and a part of them becomes refractory. Thus, it is needed to fully understand the pathophysiology of phantom limb pain for the development of effective treatments. To elucidate the central mechanisms of phantom limb pain, functional and anatomical changes in the brain has been explored by using noninvasive brain activity recording technique such as electroencephalography (EEG), magnetoencephalography (MEG) and functional magnetic resonance imaging (fMRI). In 1995, Flor and colleagues reported that the somatotopic organization of the primary somatosensory cortex had altered in patients with phantom limb pain and the magnitude of this alteration had been associated with the intensity of their phantom limb pain. Based on these results, they proposed a model that alterations in the somatotopic organization of a missing hand are involved in phantom limb pain. Now, this model is known as the maladaptive reorganization model. Over the following 20 years, a variety of supporting evidence has been provided, and this model has been widely accepted. However, Makin and colleagues provided evidence against this model in 2013. They demonstrated that cortical representation of a missing hand had been preserved and activation evoked by phantom limb movement had been related to the severity of phantom limb pain. After that, the maladaptive reorganization model has been revisited, and recent studies have suggested that functional alterations in the primary motor cortex rather than the primary sensory cortex are associated with phantom limb pain. Most recently, by using brain-machine interface technology, Yanagisawa and colleagues demonstrated that the activity of the missing hand area in the sensorimotor cortex is closely related to phantom limb pain. However, detailed neural mechanisms of phantom limb pain remain unclear so far, although many changes in the peripheral and central nervous system after amputation have been found in phantom limb pain patients. Therefore, new models integrating various findings and further studies designed specifically for verifying the new models are needed in the future, to fully understand the pathophysiology of phantom limb and phantom limb pain.
\end{abstract}


Keywords

Somatotopic reorganization; Cortical representation; Functional alterations;

Non-invasive brain activity recording; Brain-machine interface

Received: 31 January 2019

\section{幻肢痛における脳の機能的・構造的変化}

\section{寒 重之}

大阪大学大学院医学系研究科 生体統御医学講座

\section{はじめに}

四肢の切断後に，失った四肢があたかも存在 するように感じる錯覚を幻肢という。また，こ の幻肢に感じる痛みを幻肢痛と呼ぶ。幻肢痛の 発生頻度は四肢切断患者の 45～85\%とされ，そ の一部は長く続く痛みに苦しめられる 11)。

四肢切断後には，未梢神経系だけでなく，脳 を含む中枢神経系においても，さまざまな変化 が生じる ${ }^{5)}$ (Fig.1)。これらが複合して，幻肢お よび幻肢痛を引き起こすと考えられているが, その中でもっともよく知られ，これまでに多く の研究で検討されているのが，一次体性感覚野 （SI）における体部位再現マップの変化, いわゆ る「大脳皮質の機能的再構築 (cortical reorganization)」と幻肢痛の関係である。

1995 年の Flor らの報告 ${ }^{4)}$ 以来, 複数の研究 でSI の機能的再構築と幻肢痛との関連が確認 されている。また, 治療介入後の痛みの減少に 伴って, 変化していた体部位再現マップが元に 戻ることも確認されている。これらの報告を受 け, SI における体部位再現マップの変化, 特に 失った四肢に対応する皮質表象の減少・消失が,
幻肢痛の発生と維持に中心的な役割を担うとい う考えが広く受け入れられるようになった5)。 しかし，2013 年に Makin らによって幻肢痛の 重症度が高い患者ほど幻肢を動かすことで生じ る一次感覚運動野の活動が大きいという報告 14) がなされて以降, 機能的再構築と幻肢痛との関 連に疑問を呈するような報告が相次ぎ, SI の機 能的再構築と幻肢痛の関連についての議論が再 び活発になっている 17)。

\section{一次体性感覚野における} 機能的再構築と幻肢痛 : maladaptive reorganization model

「ペンフィールドのホムンクルス」としてょく 知られているように, SI や一次運動野 (MI) に は, 身体部位と脳の特定の領域が一対一で対応 する体部位再現マップが存在する（Fig.2 左）。 脳の特定の部位を刺激すると, 体性感覚野であ れば対応する身体部位が触れられたように感じ， また運動野であれば対応する部位の筋肉の収縮 が誘発される。体部位再現マップ上の領域の大 きさは，手や顔や口などが他の部位に比べて広 


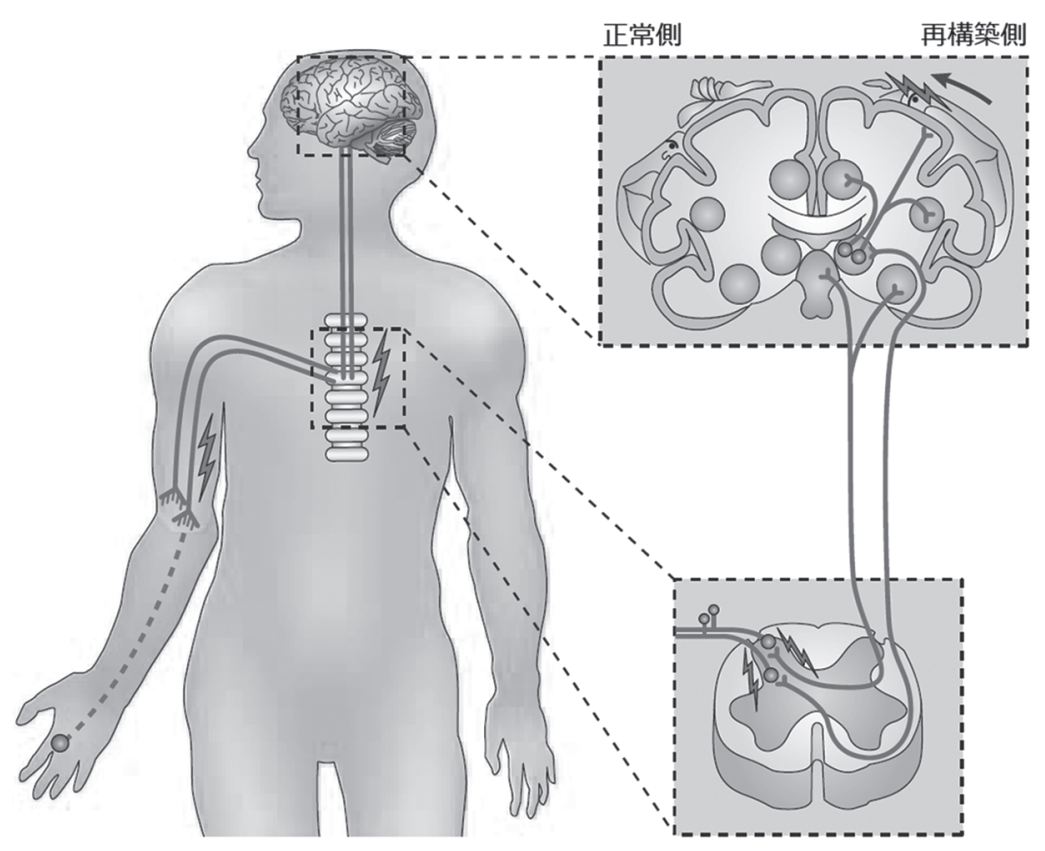

\author{
中枢神経系での変化 \\ ・アンマスキング \\ - 側芽形成 \\ - 全般的脱抑制 \\ - 皮質マップの再構築 \\ ・ 神経細胞および神経機能の喪失 \\ - 脱神経 \\ ・神経細胞およびグリア細胞における \\ 活動性の変化 \\ ・ 感覚 - 運動間および感覚間の不一致
}

Fig.1 The proposed peripheral and central mechanisms associated with phantom limb pain. Adopted and modified from REF. 5 .

A

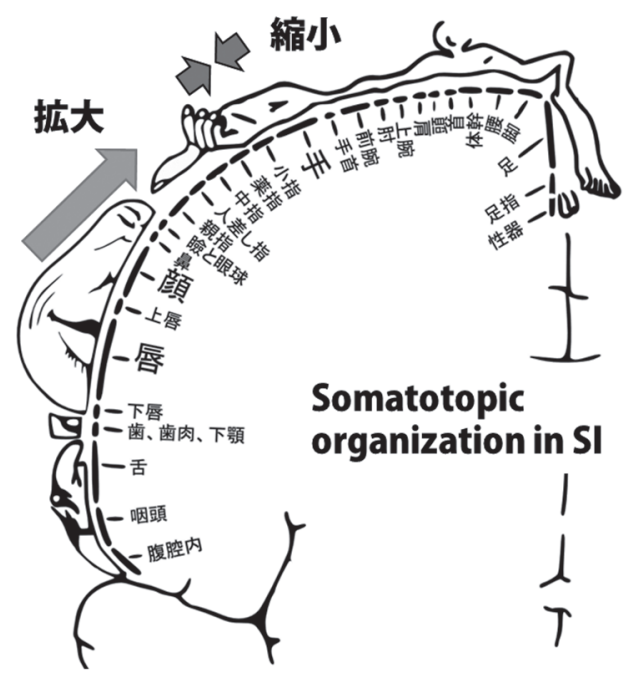

B

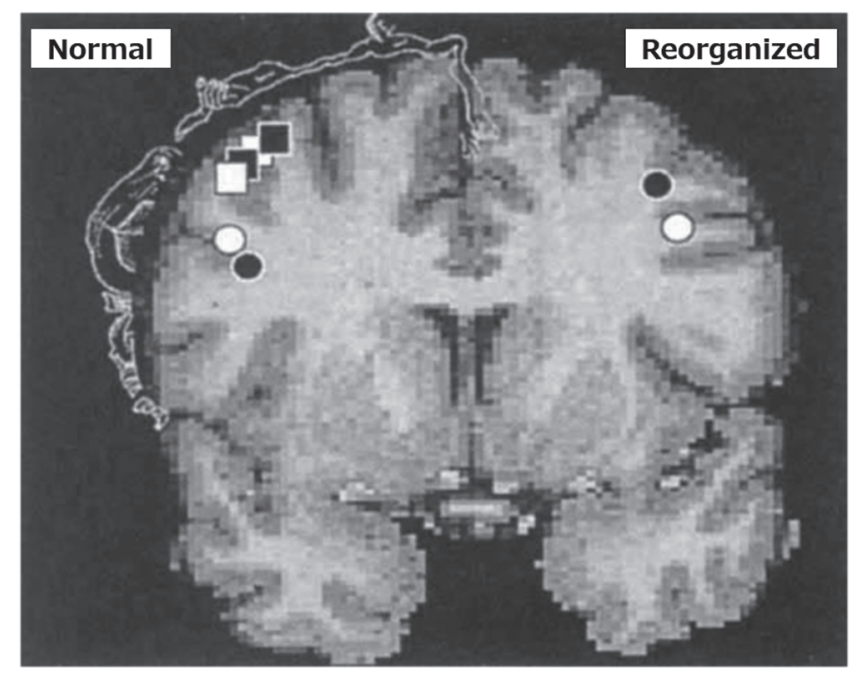

Fig.2 The schematic diagram of cortical reorganization in the primary somatosensory cortex (SI) after upper limb amputation, and the lip representations on SI in amputees with and without phantom limb pain. (A) The maladaptive reorganization model assumes that the representation of upper limb on SI diminishes and that of face, especially lips, expands after amputation. (B) Cortical representations of the digits and the lip. White symbols correspond to a patient without phantom limb pain, and black symbols correspond to a patient with intense phantom limb pain. Squares represent activation locations of the digits, and circles represent activation locations of the lip. "Reorganized" side is the hemisphere contralateral to amputation side. In the "reorganized" hemisphere, locations of the lip representations are quite different between amputees with and without phantom limb pain. Adopted and modified from REF. 4. 
A

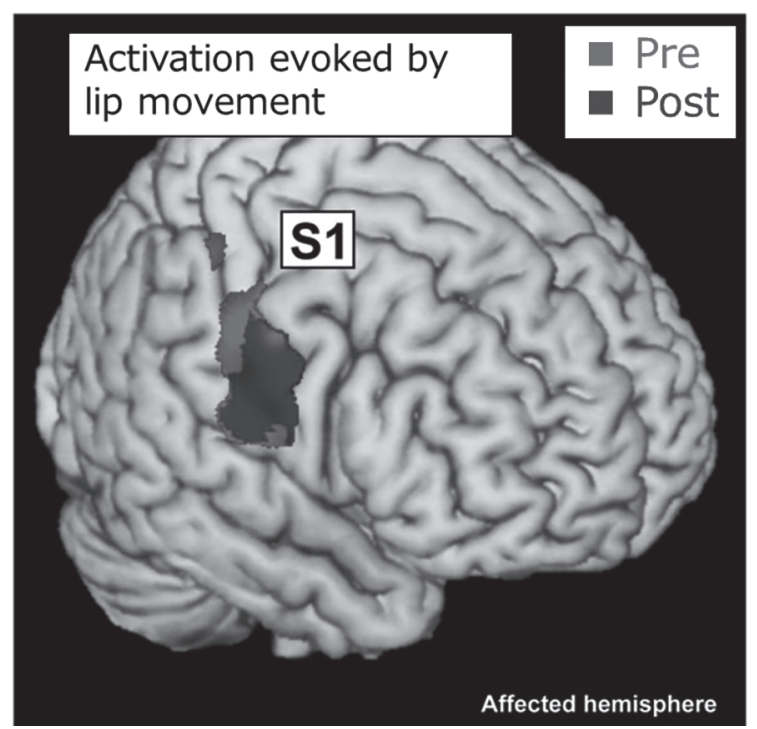

B

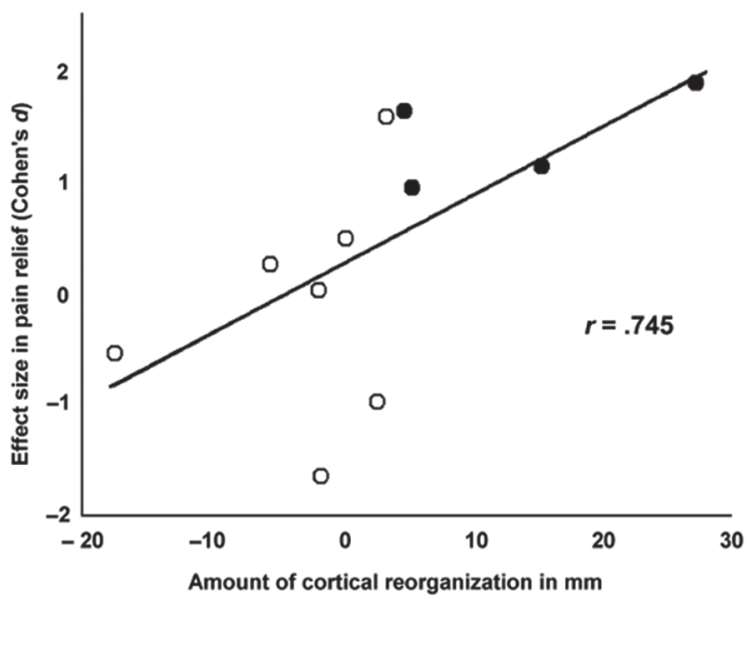

Fig.3 Cortical activations evoked by lip movement before and after mirror therapy and the relationship between the amount of pain relief and that of cortical reorganization. (A) Compared to before mirror therapy, the extent of cortical activation in the sensorimotor cortex diminished after mirror therapy. (B) Regardless of with and without telescoping (black circles correspond to patients without telescoping, and white circles correspond to patients with telescoping), patients with phantom limb pain showed a significant positive correlation between the amount of cortical reorganization and the effect size in pain relief. Adopted and modified from REF. 6.

い面積を占めており，感覚の鋭敏さと対応して いると考えられている。

この SI あるいは MI の体部位再現マップが, 四肢の切断などの求心性入力の遮断によって変 化することを，大脳皮質の機能的再構築と呼ぶ。 Flor らは, 脳磁計 (magnetoencephalography, MEG）を用いて，片側上肢切断患者の唇をブラ シでこすった時のSI における活動部位と，指 をブラシでこすった時の活動部位の距離を半球 間で比較した4)。このとき，患側肢に対応する 半球の指の領域は健側肢の指の領域の左右対称 な位置と仮定した。すると，健側上肢に対応す る半球に比べて患側上肢に対応する半球では, 唇の刺激による活動部位と指への刺激による活 動部位との距離が縮小していた（Fig.2右）。さ らに興味深いことに, 患者が訴える幻肢痛の痛 みの強さと機能的再構築の程度 (指一唇の活動
領域間の距離における左右半球間での差）との 間に正の相関がみられた。このことから, Flor らは, 四肢切断後のSI の機能的再構築は, 体 の一部に触れると失った四肢の感覚が生じると いう関連感覚 (referred sensation) だけでなく, 幻肢痛の発症や維持に関与すると主張した。 Flor の提唱したこの説は, 四肢切断後の<不適 切な皮質の機能的再構築 > が幻肢痛を引き起こ すという意味で “maladaptive reorganization model”と呼ばれ，これを董付けるさまざまな 知見から, 幻肢痛の中枢機序として広く受け入 れられるようになった。

Flor らの報告以外にも, maladaptive reorganization model を支持する知見には，次のよう なものがある。たとえば, Lotze らは fMRI を 用いて, 幻肢痛患者, 幻肢痛のない上肢切断患 者と健康成人との間で, 唇をすぼませる動きを 
したときの脳活動を比較し, 幻肢痛患者では唇 を動かしたときの賦活領域が手に対応する領域 がある背内側方向に拡大していたことを報告し ている 13)。さらに彼らは，義手を使用し幻肢痛 のない上肢切断患者は, 健康成人と同様に, 中 心溝と大脳縦裂の交点から唇の活動領域の中心 までの距離が左右半球でほほ等しいのに対して, 幻肢痛患者では切断した上肢に対応する半球で その距離が短縮していることを報告している ${ }^{12)}$ またFoell らは，鏡療法をおこなった幻肢痛患 者に押いて, 治療後の痛みの緩和の程度は唇の 動きによって生じる活動領域の縮小の程度と正 の相関があったことを報告している (Fig.3) 6)。

\section{Maladaptive reorganization model $へ の$ 疑問}

これまでに見てきたように, 四肢の切断後に おこるSI の機能的再構築が幻肢痛の発症・維持 に関連しているとする maladaptive reorganization model は，さまざまな知見により支持され てきた。しかし, 2013 年の Makin らの報告以降, さまざまな観点から maladaptive reorganization model の再検討がなされている。

2013 年の Makin らの研究は, これまでの報 告のようにSI 上の手の領域に隣接する顔, 特 に唇を動かしたり, 触ったりしたときの脳活動 を調べるのではなく, 幻肢を動かしたときの脳 活動と日常の幻肢痛の程度との関連を検討した

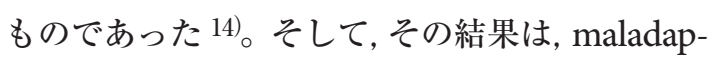
tive reorganization model では縮小・消失してい るはずの切断した上肢に対応する SI および MI 上の領域の活動は, 幻肢痛の重症度が高い患者 ほど大きいというものであった。その後も， Makin らのグループは積極的に maladaptive reorganization model の再検討を進め, 切断し
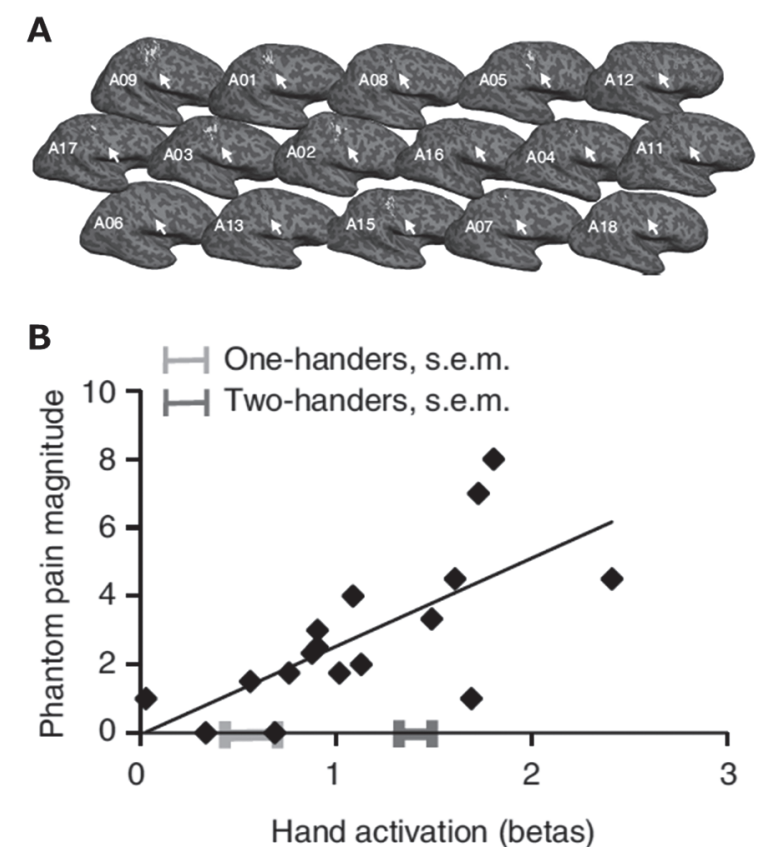

Fig.4 Cortical activation evoked by phantom limb movement and the relationship between the amount of activation and the severity of phantom limb pain. (A) All patients with phantom limb pain showed activation of the sensorimotor cortex evoked by phantom limb movement, but the amount of activation differed among these patients. (B) The amount of activation evoked by phantom limb movement was positively correlated with the severity of phantom limb pain. Adopted from REF. 14.

た上肢に対応する半球の SI では唇の領域は手 の領域の方向に拡大するものの, 手の領域に侵 入するまでには至らないこと，またこのような 唇の領域の拡大の大きさと幻肢痛の重症度とに は有意な相関はみられないことを報告してい る16)。さらに, 上肢切断患者であっても切断し た指の表象がSI に残存しており ${ }^{8)}$, 機械学習を 用いることでこの部位の活動から幻肢の指の ジェスチャーを予測することができることを報 告している1)。Makin のグループ以外からも, SI の機能的再構築が幻肢痛に特異的に関係する わけではないことを示す結果が報告されている。 Simões らは, 幻肢痛のない下肢切断患者と健 


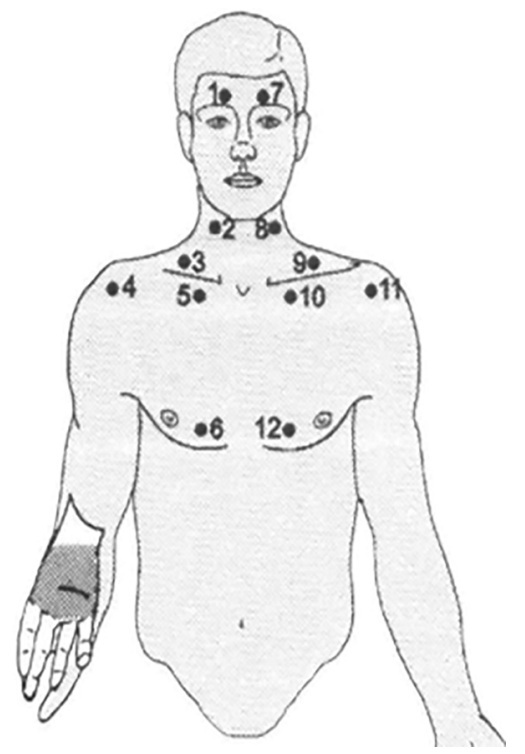

Fig.5 Trigger points evoking referred sensation in a patient to stimulation by touch. Adopted from REF. 10.

康成人とで切断部に近接した身体部位をブラッ シングしたときの脳活動を比較して，幻肢痛が なくても下肢切断患者では刺激に対して賦活さ れる領域が拡大しており，機能的再構築が生じ ていること示した 19)。Makin は，これらの結果 を踏まえ, maladaptive reorganization model に 疑問を呈している 17)。

Makin は，さらに 2017 年の総説の中で，機 能的再構築に関して，もしそれが生じているの であれば観察されるであろう幻肢痛以外の感覚 上の変化がみられないことから, maladaptive reorganization model の再考を促している17)。 たとえば，先に身体部位に対応するSI 上の領 域の広さが感覚の鋭敏さと関連していると述べ たが，指を使った刺激弁別課題の正答率を指を 切断した患者と健康成人で，また患者の患側と 健側で比較しても，有意な差はみられなかった という Vega-Bermudez と Jhonson の知見 ${ }^{20)}$ が ある。また，四肢切断後の機能的再構築からは， 関連感覚は失った体部位に隣接する領域に触れ
たときだけに生じると考えられるが，直接隣り 合わない身体部位に触れても関連感覚が生じる という Knecht ら報告 10) も, maladaptive reorganization model を否定する知見である (Fig.5)。

興味深い指摘としては, maladaptive reorganization model を直接支持する知見は考えられ ているよりもずっと限られているというものが ある。2015 年の Jutzeler と Kramer の報告によ ると，症例報告を除き $\mathrm{fMRI}$ を用いてヒトで四 肢の切断と幻肢痛と関係を検討した研究はわず か 8 本しかなく, しかもそのうちの 3 本は機能 的再構築と幻肢痛との関係は認められないとの 結果であった7)。

\section{四肢切断後の一次体性感覚野以外での} 脳の変化

Maladaptive reorganization model については, Makin らのグループを中心にそれを否定する知 見が報告されているが，四肢切断後に起こる SI の機能的再構築以外の脳の変化についての報告 もこれまでになされている。

脳の解剖学的変化を調べる手法として, T1 強調構造画像を用いて灰白質の容積や厚さを測 る手法がある。Draganski らは, 健康成人に対 して幻肢痛患者において, 切断した上肢と対側 の視床で灰白質容積の有意な減少がみられたと 報告している3)。また, Preißler らは, 上頭頂 小葉, 中側頭溝, 側頭極, 左背外側前頭前野, 紡錘状回で灰白質容積の増加が，また右背外側 前頭前野, 中心前回では灰白質容積の減少が幻 肢痛患者でみられたと報告している18)。さらに， 幻肢痛の重症度が高い群と低い群との比較では, 弁蓋部, 島皮質, 背外側前頭前野, 外側眼窩前 頭皮質，側頭回，中前頭回，中心前回，縁上回， 紡錘状回，後部帯状皮質，帯状回峡の灰白質容 
積が幻肢痛の重症度が高い群でより減少してい た 18)。Makin らは, 幻肢痛患者, 先天的片側上 肢欠損患者および健康成人で MI の灰白質容積 を比較し, 幻肢痛患者で有意な減少がみられる こと，また灰白質容積と幻肢痛の重症度との間 に正の相関がみられたことを報告している 14)。

MRI では, magnetic resonance spectroscopy という手法を用いることで，脳内における代謝 産物の量を計測することが出来る。Cirstea らは この手法を用いて, 上肢切断患者のSIにおけ る神経伝達物質の濃度を半球間で比較し, Nアセチルアスパラギン酸の濃度が患側上肢に対 応する半球でその濃度が低下していることを報 告している 2$)$

2000 年前後から, fMRI を用いて安静時の脳 活動を計測し，自発活動の脳部位間の同期性 (これを「機能的結合」と呼ぶ）を調べて，脳の ネットワークとしての状態を評価する安静時 fMRI が新たな研究パラダイムとして用いられ るようになっている。幻肢痛においても, Makinのグループが機能的結合の変化を検討し ており，幻肢痛患者では，左右 SI 間の機能的 結合が健康成人に比べて減少すること，また機 能的結合の強さは幻肢痛の重症度とは負の相関 を示すことを報告している14)。さらに，切断し た上肢に対応する領域と, 感覚・運動ネット ワークとの機能的結合は幻肢痛患者で減弱する のに対して, default mode network との機能的 結合は増強することを報告している 15)。

\section{幻肢の運動と幻肢痛との関連}

幻肢の運動の随意的な制御と幻肢痛との関連 は以前からも指摘されていたが，近年これを支 持する知見がいくつかの研究で報告されてい る。
Kikkert らは，幻肢痛患者に手の親指で他の 指を順に触るタッピングタスクをおこなわせ, その遂行にかかる時間と幻肢痛の強さ, また脳 活動との関係を検討した。その結果, 課題の遂 行にかかる時間が長いほど幻肢痛の痛みは強く, さらに遂行時間が長いほど幻肢の運動に伴う脳 活動は大きかった9)。これは, Makin らが 2013 年に報告した幻肢痛の強い患者は幻肢の運動に 伴う脳活動が大きいという関係は, 反応時間つ まり幻肢の動かしやすさという要因が介在して いることを示している。

さらに, 幻肢の運動と痛みとの関係を示す直 接的な知見を, Yanagisawa らが報告している21）。 Yanagisawa らは, 脳活動から運動の情報を取り 出して機器を動かす brain-computer interface の技術と, 脳活動を視覚情報や聴覚情報の形に 変換して対象者に見せ，その情報を基に対象者 が試行錯䛊的に脳活動を変化させるニューロ フィードバックと呼ばれる手法を用いて, 幻肢 痛患者の運動野の活動を変化させた。幻肢痛患 者にロボット義手を動かすよう求め, 患者が幻 肢を動かしたときの脳活動パターンを示した場 合に義手が動くようにした条件 (幻肢学習条件)， 実際に健側の手を動かしたときの脳活動パター ンを示した場合に義手が動くようにした条件 (健側肢学習条件), 脳活動とは無関係に一定の 確率で義手が動くようにした条件 (学習なし条 件)の 3 つの条件で義手を動かす訓練をおこな い, 訓練前後での脳活動の変化を調べると, 幻 肢学習条件では対応する運動野の活動が増加し ていた一方, 健側肢学習条件では活動は低下し, 学習なし条件では有意な変化は認められなかっ た。また, 痛みの強さの変化では, 幻肢学習条 件では痛みが増悪した一方, 健側肢学習条件で は痛みの緩和がみられた。学習なし条件では痛 みに変化はなかった。さらに, 学習前後での痛 
A

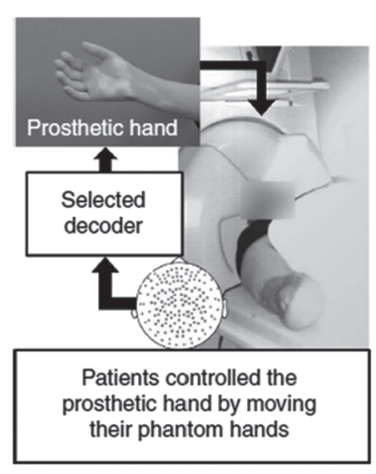

B
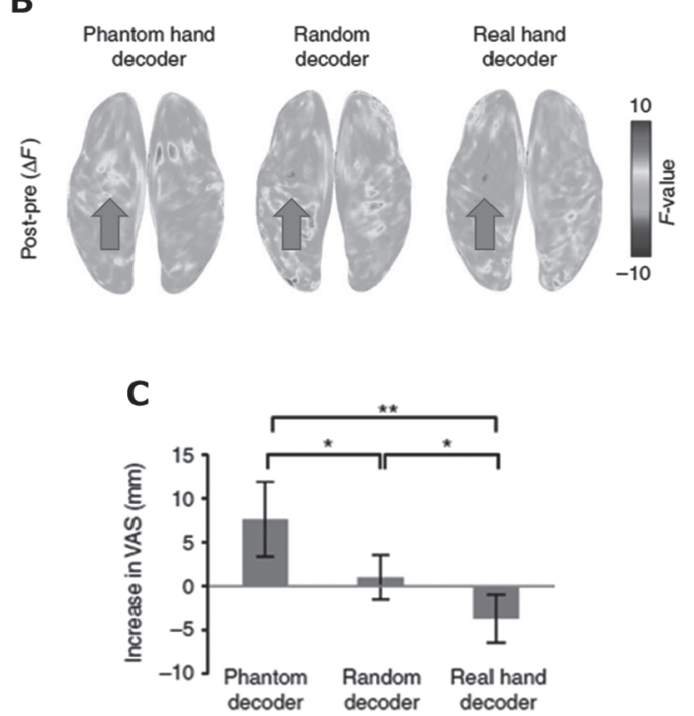

D

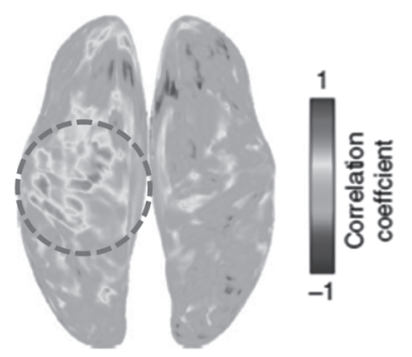

Fig.6 Brain-machine interface (BMI) training modulates not only cortical activation of the sensorimotor cortex but also the intensity of phantom limb pain. (A) A schematic diagram of the BMI trainig system with a prosthetic hand. (B) Differences of training effect on cortical activation among decoders (conditions). (C) Differences of modulation effect on the intensity of phantom limb pain among decoders (conditions). (D) Cortical areas showing the correlation between changes of brain activation and that of pain intensity. Adopted and modified from REF. 21.

みの強さの変化と脳活動の変化の関連を調べる

と, 運動野の活動の変化が学習後の痛みの変化

と有意な正の相関していた (Fig.6)。

\section{まとめ}

1995 年の Flor らの報告以来, 約 20 年に亘っ て, 四肢切断後のSI の機能的再構築, 特に切 断した四肢に対応する皮質領域の縮小と隣接す る領域の拡大が幻肢痛の発症と維持に重要な役 割を担うとする maladaptive reorganization model が支持されてきた。しかし，切断した四 肢の皮質表象は消失しておらず，反対に幻肢の 運動に伴う活動が大きいほど幻肢痛の重症度が 高いという2 2013 年の Makin らの報告以降, さ まざまな観点から maladaptive reorganization model が再検討されており, 四肢切断後に脳に 起こるどのような変化が幻肢痛と関係している
かについていまだに一定の結論は出ていない。 一方, 近年の報告では, 幻肢の運動の随意的制 御の能力や運動野の活動と幻肢痛が関連するこ とが報告されており，幻肢痛の中枢機序に関し て新たな展開を見せている。しかし，2015 年の システマティックレビューにもあるとおり，幻 肢痛患者に対する脳画像研究, 特に fMRI を用 いた研究は少ない。幻肢痛の中枢機序の解明に は, 検証可能な仮説の構築と, その仮説の検証 のために特別に計画された新たな研究の実施が 不可欠であり，今後さらなる検討が望まれる。

\section{文 献}

1) Bruurmijn, M.L.C.M., Pereboom, I.P.L., Vansteensel, M.J., Raemaekers, M.A.H., Ramsey, N.F., Preservation of hand movement representation in the sensorimotor areas of amputees, Brain, 140 (2017) 3166-3178. 
2) Cirstea, C.M., Choi, I.Y., Lee, P., Peng, H., Kaufman, C.L., Frey, S.H., Magnetic resonance spectroscopy of current hand amputees reveals evidence for neuronal-level changes in former sensorimotor cortex, J. Neurophysiol., 117 (2017) 1821-1830.

3) Draganski, B., Moser, T., Lummel, N., Gänssbauer, S., Bogdahn, U., Haas, F., May, A., Decrease of thalamic gray matter following limb amputation, Neuroimage, 31 (2006) 951-957.

4) Flor, H., Elbert, T., Knecht, S., Wienbruch, C., Pantev, C., Birbaumer, N., Larbig, W., Taub, E., Phantom-limb pain as a perceptual correlate of cortical reorganization following arm amputation, Nature, 375 (1995) 482-484.

5) Flor, H., Nikolajsen, L., Jensen, S., Phantom limb pain: a case of maladaptive CNS plasticity? Nat. Rev. Neurosci., 7 (2006) 873-881.

6) Foell, J., Bekrater-Bodmann, R., Diers, M., Flor, H., Mirror therapy for phantom limb pain: brain changes and the role of body representation, Eur. J. Pain, 18 (2014) 729-739.

7) Jutzeler, C.R., Curt, A., Kramer, J.L.K., Relationship between chronic pain and brain reorganization after deafferentation: a systematic review of functional MRI findings, NuroImage Clin., 9 (2015) 599-606.

8) Kikkert, S., Kolasinski, J., Jbabdi, S., Tracey, I., Beckmann, C.F., Johansen-Berg, H., Makin, T.R., Revealing the neural fingerprints of a missing hand, eLife, 5 (2016) e15292.

9) Kikkert, S., Mezue, M., Slater, D.H., JohansenBerg, H., Tracey, I., Makin, T.R., Motor correlates of phantom limb pain, Cortex, 95 (2017) 29-36.

10) Knecht, S., Henningsen, H., Elbert, T., Flor, H., Höhling, C., Pantev, C., Taub, E., Reorganization and perceptional changes after amputation, Brain, 119 (1996) 1213-1219.

11) Kuffler, D.P., Orgins of phantom limb pain, Mol. Neurobiol., 55 (2018) 60-69.

12) Lotze, M., Grodd, W., Birbaumer, N., Erb, M., Huse, E., Flor, H., Does use of a myoelectric prosthesis prevent cortical reorganization and phantom limb pain? Nat. Neurosci., 2 (1999) 501-502.

13) Lotze, M., Flor, H., Grodd, W., Larbig, W., Birbaumer, N., Phantom movements and pain: an fMRI study in upper limb amputees, Brain, 124 (2001) 2268-2277.
14) Makin, T.R., Scholz, J., Filippini, N., Slater, D.H., Tracey, I., Johansen-Berg, H., Phantom limb pain is associated with preserved structure and function in the former hand area, Nat. Commun., 4 (2013) 1570.

15) Makin, T.R., Filippini, N., Duff, E.P., Slater, D.H., Tracey, I., Johansen-Berg, H., Network-level reorganisation of functional connectivity following arm amputation, Neuroimage, 114 (2015) 217-225.

16) Makin, T.R., Scholz, J., Slater, D.H., JohansenBerg, H., Tracey, I., Reassessing cortical reorganization in the primary sensorimotor cortex following arm amputation, Brain, 138 (2015) 2140-2146.

17) Makin, T.R., Bensmaia, S.J., Stability of sensory topographies in adult cortex, Trends Cogn. Sci., 21 (2017) 195-204.

18) Preißler, S., Feiler, J., Dietrich, C., Hofmann, G.O., Miltner, W.H.R., Weiss, T., Gray matter changes following limb amputation with high and low intensities of phantom limb pain, Cereb. Cortex, 3 (2013) 1038-1048.

19) Simões, E.L., Bramati, I., Rodrigues, E., Franzoi, A., Moll, J., Lent, R., Tovar-Moll, F., Functional expansion of sensorimotor representation and structural reorganization of callosal connections in lower limb amputees, J. Neurosci., 32 (2012) 3211-3220.

20) Vega-Bermudez, F., Jhonson, K.O., Spatial acuity after digit amputation, Brain, 125 (2002) 1256-1264.

21) Yanagisawa, T., Fukuma, R., Seymour, B., Hosomi, K., Kishima, H., Shimizu, T., Yokoi, H., Hirata, M., Yoshimine, T., Kamitani, Y., Saitoh, Y., Induced sensorimotor brain plasticity controls pain in phantom limb patients, Nat. Commun., 7 (2016) 13209.

Address for correspondence: Shigeyuki Kan Department of Anesthesiology and Intensive Care Medicine, Osaka University Graduate School of Medicine

2-2 Yamadaoka, Suita, Osaka 565-0871, Japan

※ 本稿は第 40 回日本疼痛学会 (2018 年 7 月, 長崎) 「シンポジゥム 2 : 幻肢痛のメカニズムと新規治療 戦略」の講演内容をまとめたものである。 